(c) 2016

\title{
Protected lipids and fatty acids in rations of feeding of cattle
}

\section{S. Vovk,}

\section{Doctor of Biological Sciences}

S. Pavkovych,

Candidate of Agricultural Sciences

Lviv National Agrarian University

The purpose. To analyze results of domestic and foreign scientific probes of last years as to productive and metabolic influence, increase of productivity of fatty additives in rations of feeding of different age and productive groups of cattle. Methods. Analytical, theoretical generalization. Results. Results of own probes, domestic and foreign authors carried out in last years concerning metabolic and productive action of protected lipids and fatty acids at use of their additives in rations of feeding of different age and productive groups of cattle are brought. Conclusions. Utilization in structure of rations of different age and productive groups of cattle of additives of the protected fats and polyene fatty acids of vegetable origin stimulates metabolism at animals, increases their productivity and improves quality of milk and beef. The most effective is use in structure of rations of young stock and adult animals of additives of calcium salts of fatty acids made on the basis of sunflower, soybean, canol rape, linen and palm oils.

Key words: cattle, feeding, lipids, fatty acids.

Introduction. Numerous researches prove that application of added vegetable and animal fats in animal diet makes stimulating effect on metabolism, intensity of the animal growth and development, forage payments, slaughtering output, food and biological value of animal products [3]. Such effect is forced by high-energy coefficient of fats, their nitrogen-holding action in bodies, positive impact on regulation of metabolic processes, accumulation of fat-soluble vitamins in tissues [5]. Modern intensive technologies of animal breeding expect, as a rule, application of added fats in diets.

Peculiarities of anatomy and functioning of intestinal track force some substantial differences in application of added fats in diel of ruminants, as compared to nonruminant ones. Particularly, there are some peculiarities in application of added fats in diets of cattle because of presence of forestomaches and importance of symbiotic rumen microorganisms in digestive processes and metabolism [26].

It is confirmed that high level of vegetable and animal fats in cattle diets, in the period of active functioning of forestomaches, inhibits metabolic activity of a set of rumen microorganisms. It is also demonstrated that intensive breakdown of alimentary lipids and hydrogenation of polyenoic fatty acids by ferment systems of microorganisms in cattle forestomaches, results in degradation of a considerable amount of essential (linoleic and linolenoic) and other fatty acids, making negative impact on food and biological quality of milk and beef. Considering the above-mentioned reasons, countries with developed cattle farming have lately carried intensive scientific researches concerning increase of efficiency of added fats application in diet of the kind of animals.

The present article gives results of personal researches, as well as of domestic and foreign authors of the latest years concerning metabolic and productive effect of protected lipids and fatty acids in application of their additives in diets of different age and productive groups of cattle.

Main material. Results of experimental researches prove that increased level of fats and fatty acids in cattle diets inhibits fermentation processes in rumen, decreases digestion of organic substances in forestomaches and intestinal track in general. Among fatty acids, coming into cattle body with forage, essential polyunsaturated (linoleic and linolenoic) fatty acids constitute $70-85 \%$, while in milk and beef, their share makes only $4-8 \%$ [1]. It happens because in the kind of animals, polyenoic fatty acids are subjected to active hydrogenation under the impact of ferment systems of rumen microorganisms. Thus, their share in small bowel considerable decreases and concentration of saturated acids increases [26]. It is a well-known 
fact that polyenoic (linoleic and linolenoic) and other unsaturated fatty acids make anticancerogenic, antisclerotic and anti-inflammatory effect in animals' bodies [25]. Besides, the mentioned fatty acids stimulate reproductive functions of cows and heifers, support expression of reproductive genes, are substrates for synthesis of estrogens, progesterone and prostaglandins, activate metabolic processes in follicular, oocytes, supply growth and development of embryos [17]. Considering everything mentioned above, different methods are used to protect vegetative and animal fats before giving them to animals in order to reduce negative effect of alimental fats on metabolic activity of symbiotic microorganisms of cattle forestomaches, raise income of polyenoic fatty acids from bowel into blood stream and increase share of polyunsaturated fatty acids in the content of milk fat and beef [18].

Feeding of cattle with a certain amount of native seed of oilseeds, which contains lipids and is protected with seed coat, is the simplest and cheapest way to protect polyunsaturated fatty acids from biohydrogenation and prevent their negative effect on living activity of rumen microorganisms [4]. It is argued that short-term application of flax seed additives in cow diet forces some increase of milk productivity, but does not influence share of milk fat, protein [20] and lactose, while long-lasting application of the additives does not increase milk productivity [19]. It is noted, that feeding of lactation cows with flax seed additives insufficiently increases share of unsaturated fatty acids in content of milk lipids [21], and it is also determined that feeding with sunflower seed practically does not protect unsaturated fatty acids from hydrogenation in rumen [27]. The research demonstrates that feeding of young cattle with shattered seed of oilseeds increases level of polyunsaturated fatty acids in content of lipids of muscular and fatty tissues [22], other researchers prove poor increase of polyenoic fatty acids in animals' tissue lipids in case of their feeding with the mentioned feeding additives [8].

Numerous data prove that level of hydrogenation of polyunsaturated fatty acids by fermentation microorganisms of ruminant forestomaches can be decreased by extruding of seed of oilseeds before giving it to animals. Particularly, application of extruded seed of flax in the diet of milking cows causes some increase of the share of unsaturated fatty acids in milk fat. However, according to the other data, application of extruded seed of oilseed in cattle diet practically does not reduce biohydrogenation of unsaturated fatty acids in rumen [14].

According to the data of other authors [15], application of full seed of rape, processed with hydrogen peroxide, results in some increase of income of unsaturated fatty acids into small bowel, as compared to unprocessed shattered rapeseed. However, according to the data of some other researchers [28], application of rape seed, processed with hydrogen peroxide, in the diet of lactation cows reveals the same effect on milk productivity, fatty acid content of milk fat and quality of milk, as it is in case of feeding with native shattered rapeseed.

It is confirmed [13] that radiation of flax seed with infrared light (micronization), before giving it to cows, insufficiently increases share of unsaturated fatty acids in milk fat.

Analysis of the published data of recent years prove that production of calcium salts, basing on unsaturated fatty acids, is the most widely spread and efficient chemical means to protect the acids in vegetable fats, fed to cattle [2, 3, 7, 9-11]. Calcium salts of polyenoic fatty acids are stable under conditions of rumen $\mathrm{pH}$, almost are not subjected to hydrogenation by microorganisms in the chamber of intestinal track, and moving to abomasum and small bowel, set calcium ions free, are absorbed by mucous coat of small bowel and transported by blood to organs and tissues. Some researches prove that application of calcium salts of fatty acids in cattle diet does not deteriorate fermentation processes in rumen, supports protection of $\mathrm{pH}$ of its environment, does not depress living activity of rumen microflora [7], does not reduce digestion of diet nutrients, does not inhibit production of volatile fatty acids and supplies optimal vinegarpropionic ratio in rumen, increases adsorption of calcium in gastro-intestinal tract and positively effects animals' health [30]. Calcium salts are well digested in gastro-intestinal tract of cattle, not deteriorating digestion processes in general.

Feeding cows with calcium salts of fatty acids, produced on the base of vegetable oils, increases milk productivity, share of fat and lactose in milk, but share of protein lightly decreases, while its general production does not fall [10]. Besides, application of calcium salts of fatty acids in lactation cows diet enables 
reduction of the share of saturated and increase of the level of unsaturated fatty acids, including share of linoleic acid in milk fat $[3,11]$.

It is determined that application of calcium salts of fatty acids, produced on the base of palm oil and codliver oil, in cows diet activates progress of metabolic processes in their body, stimulates wish and fertility, optimizes luteolysis, increases level of progesterone and $F_{2 a}$ prostaglandin in blood [2, 9].

Feeding of cattle with calcium salts of fatty acids, produced on the base of vegetable oils, increases share of unsaturated fatty acids in body tissues [3,12].

Covering of lipids and polyenoic fatty acids with protein-formaldehyde coat is another chemical way to protect them [16]. In acid environment of abomasum, protection coat is destroyed, released protein is split up by digestion ferments, and fatty acids, including polyenoic ones, are actively absorbed in mucous coat of small bowel, that substantially increases their share in tissues of the body, and thus, in animal products (milk, beef) [6].

Some authors say that protection of vegetable fats in the form of protein-formaldehyde complexes is sometimes low-efficient step, because of physical splitting up of the product while chewing in mouth cavity, as well as in case of unsatisfactory control for the progress of the mentioned processing. It is also marked that production of such lipid-protein-formaldehyde feeding additives requires much expenses [24].

It is demonstrated that application of rapeseed, processed with formaldehyde, in cows diet, does not influence level of milk productivity and share of protein in milk, while share of unsaturated fatty acids in milk lipids increases. However, its application in animal breeding has been lately forbidden in some countries, because of cancerogenic action of formaldehyde [29].

It is defined that incapsulation of lipid-fatty acid feeding additives with calcium alginate, before cattle feeding, is of low efficiency [23].

\section{Conclusions.}

Making conclusion of the mentioned published data, one should note that application of additives of protected fats and polyenoic fatty acids of vegetable origin in the diet of different age and productive groups of cattle makes positive metabolic and productive effect for the kind of animal. One should stress that application of calcium salts of fatty acids, produced on the base of vegetable oils, in the diets of young cows, is the most widely spread and efficient way.

\section{Bibliography}

1. Alyev A. A. Lypydnыy obmen y produktyvnost' zhvachnыkh zhyvotnыkh/A. A. Alyev - M. : Kolos, 1980. $-381 \mathrm{~s}$.

2. Vovk S. O. Stymulyatsiya reproduktyvnykh funktsiy u samok zhuynykh tvaryn dobavkamy do ratsioniv poli nenasychenykh zhyrnykh kyslot/S. O. Vovk, S. Ya. Pavkovych, Ya. D. Petrynyak//Problemy zooinzheneriyi ta veterynarnoyi medytsyny : Zb. nauk. prats' Kharkivs'koyi derzhavnoyi zooveterynarnoyi akademiyi. - Kh. : RVV KhDZVA, 2013. - Vyp. 25, Ch. 1. - S. 189-198.

3. Zhyrovi dobavky u hodivli tvaryn i ptytsi : monohrafiya/[Vovk S. O., Snityns'kyy V. V., Pavkovych S. Ya., Kruzhel' B. B.]. - L'viv : SPOLOM, 2011. - 208 s.

4. Kennel D. D. Vlyyanye rastytel'nыkh masel $v$ ratsyone zhyvotnыkh na sostav moloka/D. D. Kennel//Efektyvne tvarynnytstvo. - 2007. - \# 3. - S. 50-53.

5. Yanovych V. H. Obmen lypydov u zhyvotndkh v ontoheneze/V. H. Yanovych, P. Z. Lahodyuk - M. : Ahropromyzdat, 1991. - 317 s.6. Banks W. Effect of dietary unsaturated fatty acids in various forms on the de novo synthesis of fatty acids in the bovine mammary gland/W. Banks, J. L. Clapperton, A. K. Gildler//J. Dairy Res. - 1990. - V.57, N2. - P. 179-185.

7. Effect of unsaturated fatty acid supplementation on digestion, metabolism and nutrient balance in dairy cows during the transition period and early lactation/F. P. Renno, J. E. F. Junior, J. R. Gandra [et al.]//R. Bras. Zootec. - 2014. - Vol.43, N4. - P. 212-223.

8. Effects of feeding whole cottonseed and cottonseed products on performance and carcass characteristics of finishing beef cattle/J. J. Cranston, J. D. Rivera, M. L. Galyean [et al.]/J. Anim. Sci. - 2006. - Vol. 84, N 8. - P. 2186-2199. 
9. Effects of calcium salts of polyunsaturated fatty acids on productive and reproductive parameters of lactating Holstein cows/M. M. Reis, R. F. Cooke, J. Ranches [et al.]//J. Dairy Sci. - 2012. - Vol. 95, N 12. P. 7039-7050.

10. Fat addition in the diet of dairy ruminants and its effects on productive parameters/L. Andrés, $M$. Martínez, M. Pérez [et al.]/Rev. Colomb. Cien. Pec. - 2013. Vol. 26. - P. 69-78.

11. Fatty acid profile and composition of milk protein fraction in dairy cows fed long-chain unsaturated fatty acids during the transition period/F. P. Renno, J. E. F. Junior, J. R. Gandra [et al.]/R. Bras. Zootec. 2013. - Vol.42, N11. - P. 813-823.

12. Gillis M. H. Effects of supplemental rumen-protected conjugated linoleic acid or corn oil on fatty acid composition of adipose tissues in beef cattle/M. H. Gillis, S. K. Duckett, J. R. Sackmann//J. Anim. Sci. 2004. - Vol. 82. - P. 1419-1427.

13. Glasser F. Oilseed lipid supplements and fatty acid composition of cow milk: a meta-analysis/F. Glasser, A. Ferlay, Y. Chilliard//J. Dairy Sci. - 2008. - Vol. 91. - P. 4687-4703.

14. Grummer R. R. Effect of feed on the composition of milk fat/R. R. Grummer//J. Dairy Sci. - 1991. Vol. 74, N 9. - P. 3244-3257.

15. Hussein H. S. Effects of chemical treatment of whole canola seed on digestion of long-chain fatty acids by steers fed high or low forage diets/H. S. Hussein, N. R. Merchen, G. C. Jr. Fahey//J. Dairy Sci. - 1996. - Vol. 79, N 1. - P. 87-97.

16. Influence of ruminal biohydrogenation on the feeding value of fat in finishing diets for feedlot cattle/R. A. Zinn, S. K. Gulati, A. Plascencia [et al.]//J. Anim. Sci. - 2000. - V.78, N7. - P. 1738-1746.

17. Jahanian $E$. The dietary fatty acids and their effects on reproductive performance of ruminants/E. Jahanian, H. A. Nanaei, N. M. Kor//Europ. J. Exp. Biol. - 2013. - Vol. 3(6). - P. 95-97.

18. Lock A. L. Modifying milk fat composition of dairy cows to enhance fatty acids beneficial to human health/A. L. Lock, D. E. Bauman//Lipids - 2004. - Vol. 39. - P. 1197-1206.

19. Petit H. V. Milk production, milk composition, blood composition, and conception rate of transition dairy cows fed different fat sources/H. V. Petit, C. Benchaar//Can. J. Anim. Sci. - 2007. - Vol. 87. - P. 591600 .

20. Petit H. V. Milk concentrations of the mammalian lignans enterolactone and enterodiol, milk production, and whole tract digestibility of dairy cows fed diets containing different concentrations of flaxseed meal/H. V. Petit, N. Gagnon//Anim. Feed Sci. Technol. - 2009. - Vol. 152. - P. 103-111.

21. Petit H.V. Milk production and composition, milk fatty acid profile, and blood composition of dairy cows fed whole or ground flaxseed in the first half of lactation/H. V. Petit, C. Côrtes//Anim. Feed Sci. Technol. 2010. - Vol. 158. - P. 36-43.

22. Postpartum supplemental fat, but not maternal body condition score at parturition, affects plasma and adipose tissue fatty acid profiles of suckling beef calves/S. L. Lake, E. J. Scholljegerdes, T. R. Weston [et al.]//J. Anim. Sci. - 2006. - Vol. 84, N 7. - P. 1811-1819.

23. Ruminal biohydrogenation of fatty acids from high-oleate sunflower seeds/ P. A. Ekeren, D. R. Smith, D. K. Lunt [et al.]//Anim. Sci. - 1992. - V.70. - P. 2574-2580.

24. Ruminant milk fat plasticity: nutritional control of saturated, polyunsaturated, trans and conjugated fatty acids/Y. Chilliard, A. Ferlay, M. M. Rosemary [et al.]//Ann. Zootech. - 2000. - V.49. - P. 181-205.

25. Suksombat W. Milk production, milk composition, live weight change and milk fatty acid composition in lactating dairy cows in response to whole linseed supplementation/W Suksombat, C. Meeprom, R. Mirattanaphrai //Asian Australas. J. Anim. Sci. - 2013. - Vol. 26 (8) - P. 1111-1118.

26. Supplementation with calcium salts of linoleic and trans-octadecenoic acids improves fertility of lactating dairy cows/S. O. Juchem, R. L. Cerri, M. Villasenor [et al.]//Reprod. Domest. Anim. - 2010. - Vol. 45. - P. 55-62.

27. The effect of whole sunflower seeds on the flow of fat and fatty acids through the gastrointestinal tract of cannulated Holstein steers/B. G. White, J. R. Ingalls, 1987. - Vol. 67, N 2. - P. 447-459.

H. R. Sharma [et al.]//Canad. J. Anim. Sci. - 
28. The effects of chemical treatment of whole canola seed on intake, nutrient digestibilities, milk production, and milk fatty acids of Holstein cows/C. G. Aldrich, N. R. Merchen, J. K. Drackley [et al.]//J. Anim. Sci. - 1997. - Vol. 75, N 2. - P. 512-521.

29. World Health Organization. International Agency for Research on Cancer. Press Release N153. 2004. - http://www.iarc.fr/pageroot/PRELEASES/pr153a.html.

30. Zinn R. A. Interaction of dietary calcium and supplemental fat on digestive function and growth performance in feedlot steers/R. A. Zinn, Y. Shen//J. Anim. Sci. - 1996. - V.74, N10. - P. 2303-2309. 